\title{
Nature and severity of dental malocclusion in children suffering from transfusion-dependent $\beta$-thalassemia major
}

\author{
Waqar Jeelani ${ }^{1}$, Uroosa Sher $^{2}$, Maheen Ahmed
}

DOI: https://doi.org/10.1590/2177-6709.25.6.26.e1-9.onl

\begin{abstract}
Objective: To evaluate the prevalence and severity of malocclusion in children suffering from $\beta$-thalassemia and to assess orthodontic treatment need using Grainger's Treatment Priority Index (TPI) and index of orthodontic treatment need (IOTN)-dental health component (DHC). Methods: A cross-sectional study was conducted on 200 transfusion-dependent children diagnosed with homozygous $\beta$-thalassemia and 200 healthy school children aged 11-17 years. The TPI and IOTN-DHC data was recorded for both groups. Total TPI score for each subject was calculated and graded according to malocclusion severity estimate (MSE). Independent sample $t$-test was used to compare mean TPI scores, overjet and overbite between thalassemic and healthy children. Chi-square test was used to compare the frequency of IOTN-DHC grades, Angle's classification, and MSE grades between thalassemic and healthy children. Results: The most prevalent malocclusion was Class I in normal children (67.5\%) and Class II in thalassemic children (59\%). The mean overjet and overbite were significantly $(p<0.001)$ greater in thalassemic children than in healthy children. Severe tooth displacements were 3.5 times greater in thalassemic children, compared to controls. A greater proportion of thalassemic children were in IOTN grades 3 and 4, compared to the controls $(p<0.001)$. MSE grades 4 and 5 were significantly $(p<0.001)$ more prevalent in thalassemic children, compared to the controls. Conclusion: There is a high prevalence of Angle's Class II malocclusion in thalassemic children. Majority of these children are categorized in higher grades of IOTN-DHC and TPI-MSE, showing a great severity of malocclusion and high orthodontic treatment needs.
\end{abstract}

Keywords: Thalassemia. Beta-thalassemia. Index of orthodontic treatment need. Malocclusion.

Objetivo: Avaliar a prevalência e gravidade da má oclusão em crianças que sofrem de beta-talassemia e mensurar a necessidade de tratamento ortodôntico usando o Índice de Prioridade de Tratamento (IPT) de Grainger e o Índice de Necessidade de Tratamento Ortodôntico (Index of Orthodontic Treatment Need - IOTN) - Componente de Saúde Dental (Dental Health Component - DHC). Métodos: Um estudo transversal foi conduzido com 200 crianças com diagnóstico de beta-talassemia homozigótica dependentes de transfusão e 200 crianças saudáveis em idade escolar, entre 11 e 17 anos. Os dados do IPT e do IOTN-DHC foram documentados para ambos os grupos. A pontuação total do IPT para cada sujeito foi calculada e classificada de acordo com a Estimativa de Severidade da Má oclusão (ESM). O teste $t$ para amostras independentes foi usado para comparar os escores médios de IPT, sobressaliência e sobremordida, entre as crianças saudáveis e as com talassemia. O teste qui-quadrado foi usado para comparar a frequência dos escores do IOTN-DHC, a classificação de Angle e os escores do ESM entre crianças com beta-talassemia e crianças saudáveis. Resultados: A má oclusão mais prevalente foi a Classe I em crianças normais $(67,5 \%)$ e a Classe II em crianças com beta-talassemia (59\%). Os valores médios de sobressaliência e a sobremordida foram significativamente $(p<0,001)$ maiores em crianças com beta-talassemia do que em crianças saudáveis. Os deslocamentos dentários graves foram 3,5 vezes maiores em crianças com beta-talassemia em comparação com os controles. Uma proporção maior de crianças com beta-talassemia estava nos escores 3 e 4 do IOTN em comparação com os controles $(p<0,001)$. Os escores 4 e 5 de ESM foram significativamente $(p<0,001)$ mais prevalentes em crianças com beta-talassemia em comparação com os controles. Conclusão: Há uma alta prevalência de má oclusão de Classe II de Angle em crianças com beta-talassemia. A maioria dessas crianças é categorizada em escores superiores de IOTN-DHC e IPT-ESM, mostrando uma grande gravidade de má oclusão e alta necessidade de tratamento ortodôntico.

Palavras-chave: Talassemia. Beta-talassemia. Índice de necessidade de tratamento ortodôntico. Má oclusão.

${ }^{1}$ Bakhtawar Amin Medical and Dental College, College of Dentistry (Multan, Pakistan).

${ }^{2}$ Sundas Foundation,Blood Bank and Hematological Services Charitable Organization (Sialkot, Pakistan)

» The authors report no commercial, proprietary or financial interest in the products or companies described in this article.
How to cite: Jeelani W, Sher U, Ahmed M. Nature and severity of dental malocclusion in children suffering from transfusion-dependent $\beta$-thalassemia major. Dental Press J Orthod. 2020 Nov-Dec;25.6.26.e1-9.

DOI: https://doi.org/10.1590/2177-6709.25.6.26.e1-9.onl

Submitted: June 26, 2019 - Revised and accepted: November 05, 2019

Contact address: Waqar Jeelani

Email: wjeelani@gmail.com 


\section{INTRODUCTION}

Thalassemia is one of the commonest types of hemoglobinopathies resulting from decreased synthesis of different types of polypeptide chains constituting normal adult hemoglobin molecule ( $\mathrm{HbA}, \alpha 2 \beta 2) .{ }^{1} \beta$-thalassemia is one of the severest forms of this disease, resulting from mutations in the HBB gene on chromosome 11, which ultimately leads to partial or completely nonfunctional formation of $\beta$-globin chain. Depending on the severity and type of genetic mutations, $\beta$-thalassemias may be divided into $\beta$-thalassemia major, intermedia and minor. ${ }^{2}$

With a global prevalence of about $1.5 \%$, the per annum incidence of $\beta$-thalassemia has been recorded to be 1 in 100,000 worldwide. ${ }^{3}$ Children suffering from $\beta$-thalassemia major comprise the most affected group and usually need regular blood transfusions. According to one estimate, about 5,000-9,000 transfusion-dependent $\beta$-thalassemia children are born every year in Pakistan. ${ }^{4}$ According to World Health Organization (WHO), Pakistan has the largest numbers of thalassemia major children in the world, a majority of which do not have access to the proper health facilities. ${ }^{5}$

In a $\beta$-thalassemia afflicted child, the diagnostic signs and symptoms start to become eminent within the first two years of life. The common clinical manifestations of $\beta$-thalassemia major usually originate from a severe form of chronic anemia associated with cardiac complications and hepatic pathologies. ${ }^{6,7} \mathrm{~A}$ striking abdominal enlargement by the virtue of enlarged spleen and liver is frequently observed. ${ }^{7}$ Moreover, extramedullary hematopoiesis and rapid cell turnover with consequential bone marrow expansion is a prominent feature. As a complication of iron overload, stunted growth as well as skeletal deformities with resultant osteoporosis and pathologic fractures are common. ${ }^{8}$

Regarding the pathognomonic orofacial features, the predominant ones include characteristic "Cooley's facies", marked by prominent frontal and parietal bones, saddle nose, protruded zygomas and epicanthic fold. ${ }^{9}$ The common dental features include Class II malocclusion, spacing, flaring and protrusions of maxillary anterior teeth and increased overjet. ${ }^{9,10}$ Other pathological signs such as dental caries and discolorations and xerostomia are also frequently reported. ${ }^{11,12}$

In order to deal with various dental conditions, a conservative treatment approach is preferred; while for the correction of various orthodontic dentofacial deformities and malocclusion, specialized interventions — such as the use of different orthodontic appliances (fixed, removable, functional, extraoral appliances) and, in advanced cases, surgical approach - is required. ${ }^{13,14}$ Considered a "global health burden" this issue has been neglected due to its expensive and long term treatment requirements. ${ }^{15}$ Furthermore, there are no comprehensive guidelines given by the Thalassemia International Foundation for management of oral health complications in such patients. ${ }^{16}$

Therefore, it is of paramount importance to assess the prevalence and orthodontic treatment needs in this particular lot of population, so that a generalized opinion may be formulated regarding the severity of malocclusion, burden of disease and required expertise and resources. Hence, the primary objective of this study was to evaluate the prevalence of different malocclusion characteristics in the children suffering from $\beta$-thalassemia and to assess the orthodontic treatment needs using Grainger's Treatment Priority Index (TPI $)^{17}$ and index of orthodontic treatment need (IOTN) - dental health component (DHC). ${ }^{18}$

\section{MATERIAL AND METHODS}

A cross-sectional study was conducted at the department of orthodontics, Bakhtawar Amin Medical and Dental College in collaboration with Sundas Foundation. Ethical approval was obtained from the Institutional Research Board, Bakhtawar Amin Dental College and Hospital, Multan (protocol \#309/2020), prior to the data collection.

\section{Sample selection}

A total of two-hundred transfusion-dependent children suffering from $\beta$-thalassemia major registered with Blood Bank and Hematological Services Charitable Organization were included in the study. A non-probability consecutive sampling technique was employed.

The inclusion criteria comprised of subjects diagnosed with homozygous $\beta$-thalassemia, within the age range of 11 to 17 years, receiving regular blood transfusions. Children in mixed dentition period, or those having history of any previous orthodontic treatment or any type of chronic disease or growth retardation were excluded from the study.

For the control group, a sample of 200 healthy school children, matched according to age and gender, were selected from four different schools, using stratified sampling technique, and the TPI and IOTN-DHC data was recorded. The same exclusion criteria were followed for the controls as was for the study group. 


\section{Data collection}

For the evaluation of TPI and IOTN-DHC, the main investigator was trained and the intraoral examination of all the patients, in cases and control categories, was performed by the same examiner. The data collection form recorded the patient's demographic details, IOTN-DHC grade and various parameters of TPI. The assessment of TPI parameters was carried out as follows:

" Bilateral first molar relationship depicts sagittal relation between the maxillary and mandibular first molars, and is considered normal if the mesiobuccal cusp of maxillary first molar occludes in the buccal groove of mandibular first molar. First molar relationship is defined by a constant in TPI that reflects the severity of malocclusion.

"Overjet was measured as the horizontal distance from the labial surface of the most prominent maxillary central incisor to the labial surface of mandibular central incisor, parallel to the occlusal plane.

" Overbite was measured as the amount of vertical overlap on the mandibular central incisor by the maxillary central incisor, considering the extent of coverage of crown height of mandibular central incisor. A negative overbite depicted no overlap between maxillary and mandibular incisors, and was denoted as open bite. Open bite was measured as the vertical distance between maxillary and mandibular incisors.

" Tooth displacement: was assessed as the number of teeth noticeably rotated or displaced from ideal alignment, and posterior teeth rotated above $45^{\circ}$ or anterior teeth displaced greater than $2 \mathrm{~mm}$ were given double weightage.

" Crossbite is a buccal or lingual displacement of the posterior teeth, deviating from normal cusp-fossa relationship. During TPI assessment, the number of teeth in buccal or lingual crossbite was assessed and were given respective weightages, as shown in Table 1.

In addition to these parameters, patients were examined for congenitally missing incisors and other intraoral defects. The findings of TPI were recorded and a total TPI score was computed for each subject using the Table 1 . The total TPI score for each subject was calculated and graded according to the Malocclusion Severity Estimate (MSE), as given below.

I. Virtually classic normal occlusion: TPI score $<1$.

II. Minor manifestations of malocclusion and treatment need is slight: TPI score from 1 to 3.99

III. Definite malocclusion, but treatment elective:

TPI score from 4 to 6.99
IV. Severe handicap, treatment highly desirable:

TPI score from 7 to 9.99

V. Very severe handicap with treatment mandatory: TPI score $>10$.

\section{Reliability of measurements}

The TPI scores and IOTN-DHC for the 30 patients were re-graded after one month to assess intraexaminer reliability. Intraclass correlation coefficients were performed for TPI, which showed a correlation coefficient of 0.89. The Kappa statistics were applied for IOTN-DHC, which showed a high coefficient of reliability (0.957). Thus, both assessments were found to have good intraexaminer reliability.

\section{Statistical analysis}

Independent sample $t$-test was used to compare the linear variables - like TPI scores, overjet and overbite - between the cases and controls. Chi-square test was used to compare the frequency of IOTNDHC grades, Angle's classification and other categorical variables, between cases and controls. A value of $p<0.05$ was taken as statistically significant.

\section{RESULTS}

A total of 121 male and 79 female adolescents were included in the study group, while 107 males and 93 females were included in the control group. There was no statistically significant difference $(p=0.189)$ in the gender distribution between the two groups. The mean ages of children in the study and control groups were $13.89 \pm 1.79$ and $14.1 \pm 2.07$ years, respectively. There was no statistically significant difference $(p=0.258)$ in the mean ages of the children belonging to both the groups.

The frequency of children with Angle's Class I malocclusion in thalassemic children was far less than that in normal children (38\% vs. 67.5\%). On the other hand, the prevalence of Angle's Class II malocclusion was 59\% in thalassemic children, as compared to $24.5 \%$ in normal children. Table 2 compares the prevalence of Angle's malocclusion between the cases and controls.

A greater proportion of thalassemic children were in IOTN grades 3 and 4, as compared to controls $(p<0.001)$. These results were highly significant. The distribution of cases and controls in different IOTN grades is given in Figure 1. 
Table 1 - Treatment Priority Index ${ }^{17}$

\begin{tabular}{|c|c|c|c|c|c|c|c|c|c|c|c|c|c|c|}
\hline \multirow{2}{*}{\multicolumn{3}{|c|}{$\begin{array}{l}\text { First Molar Relationship } \\
\text { (choose the appropriate column) }\end{array}$}} & \multicolumn{5}{|c|}{ (6) Distocclusion } & \multicolumn{5}{|c|}{ (7) Mesiocclusion } & \multirow[b]{2}{*}{$\begin{array}{l}\text { W } \\
E \\
\text { I } \\
G \\
H \\
T\end{array}$} & \multirow[b]{2}{*}{$\begin{array}{l}\text { Type of } \\
\text { Syndrome }\end{array}$} \\
\hline & & & \multicolumn{2}{|c|}{$\begin{array}{c}2 \text { sides } \\
\text { full Class II }\end{array}$} & $\begin{array}{l}1 \text { side } \\
\text { half Class II } \\
1 \text { side } \\
\text { full Class II }\end{array}$ & $\begin{array}{c}2 \text { sides half } \\
\text { Class } \| \\
\text { or } \\
1 \text { side full } \\
\text { Class } \|\end{array}$ & $\begin{array}{c}1 \text { side } \\
\text { half Class II }\end{array}$ & $\begin{array}{l}\mathrm{N} \\
\mathrm{E} \\
\mathrm{U} \\
\mathrm{T} \\
\mathrm{R} \\
\mathrm{A} \\
\mathrm{L}\end{array}$ & $\begin{array}{c}1 \text { side } \\
\text { half Class III }\end{array}$ & $\begin{array}{l}2 \text { sides half } \\
\text { Class III or } \\
1 \text { side full } \\
\text { Class III }\end{array}$ & $\begin{array}{c}1 \text { side } \\
\text { half Class III } \\
1 \text { side } \\
\text { full Class III }\end{array}$ & $\begin{array}{c}2 \text { sides } \\
\text { full Class III }\end{array}$ & & \\
\hline \multicolumn{15}{|c|}{ Incisor Horizontal Relationship in mm } \\
\hline \multirow{6}{*}{\multicolumn{2}{|c|}{ (1) Upper Overjet }} & $>9$ & & & 3.4 & 5.4 & 9.3 & $10+$ & 9.3 & 5.4 & 3.4 & 2.0 & & \multirow{6}{*}{ Retrognathism } \\
\hline & & 9 & & & 2.5 & 4.0 & 6.9 & $10+$ & 6.9 & 4.0 & 2.5 & 1.4 & & \\
\hline & & 8 & & & 1.8 & 2.8 & 4.8 & 8.0 & 4.8 & 2.8 & 1.8 & 1.0 & & \\
\hline & & 7 & & & 1.1 & 1.8 & 3.0 & 5.1 & 3.0 & 1.8 & 1.1 & 0.6 & & \\
\hline & & 6 & & & 0.6 & 1.0 & 1.7 & 2.9 & 1.7 & 1.0 & 0.6 & 0.4 & & \\
\hline & & 5 & & & 0.3 & 0.4 & 0.8 & 1.3 & 0.8 & 0.4 & 0.3 & 0.2 & & \\
\hline \multicolumn{15}{|c|}{ NORMAL (Counting 0) } \\
\hline \multirow{6}{*}{\multicolumn{2}{|c|}{ (2) Lower Overjet }} & 1 & & & 0.3 & 0.4 & 0.8 & 1.3 & 0.8 & 0.4 & 0.3 & 0.2 & \multirow{6}{*}{\multicolumn{2}{|c|}{ Prognathism }} \\
\hline & & 0 & & & 0.6 & 1.0 & 1.7 & 2.9 & 1.7 & 1.0 & 0.6 & 0.4 & & \\
\hline & & 1 & & & 1.1 & 1.8 & 3.0 & 5.1 & 3.0 & 1.8 & 1.1 & 0.6 & & \\
\hline & & 2 & & & 1.8 & 2.8 & 4.8 & 8.0 & 4.8 & 2.8 & 1.8 & 1.0 & & \\
\hline & & 3 & & & 2.5 & 4.0 & 6.9 & $10+$ & 6.9 & 4.0 & 2.5 & 1.4 & & \\
\hline & & $>3$ & & & 3.4 & 5.4 & 9.3 & $10+$ & 9.3 & 5.4 & 3.4 & 2.0 & & \\
\hline \multicolumn{15}{|c|}{ Incisor Vertical Relationship } \\
\hline \multirow{3}{*}{\multicolumn{2}{|c|}{$\begin{array}{l}\text { (3) Overbite in relation } \\
\text { to crown thirds }\end{array}$}} & $>3 / 3$ & & & 3.8 & 4.8 & 6.2 & 8.0 & 6.2 & 4.8 & 3.8 & 2.9 & & \\
\hline & & $3 / 3$ to $2 / 3$ & & & 2.0 & 2.4 & 3.2 & 4.1 & 3.2 & 2.4 & 2.0 & 1.5 & & Overbite \\
\hline & & $2 / 3$ to $1 / 3$ & & & 0.7 & 0.9 & 1.1 & 1.5 & 1.1 & 0.9 & 0.7 & 0.5 & & \\
\hline NORMAL & (Counting 0) & & & & & & & & & & & & & \\
\hline & & $<2$ & & & 2.0 & 2.4 & 3.2 & 4.1 & 3.2 & 2.4 & 2.0 & 1.5 & & \\
\hline (4) Open & bite in $\mathrm{mm}$ & 2 to 4 & & & 3.8 & 4.8 & 6.2 & 8.0 & 6.2 & 4.8 & 3.8 & 2.9 & & Open bite \\
\hline & & $>4$ & & & 6.3 & 7.9 & $10+$ & $10+$ & $10+$ & 7.9 & 6.3 & 4.9 & & \\
\hline (10) Teeth & displacement & No. & & & & & & & & & & & & \\
\hline & & 2 & & & 0.1 & 0.2 & 0.3 & 0.4 & 0.3 & 0.2 & 0.1 & 0.1 & & Distocclusion \\
\hline - Sum of $t$ & teeth rotated & 3 & & & 0.3 & 0.4 & 0.7 & 1.1 & 0.7 & 0.4 & 0.3 & 0.2 & & $\begin{array}{c}\text { and/or } \\
\text { posterior buc- }\end{array}$ \\
\hline $45^{\circ}$ or $2 m$ & nm displaced & 4 & & & 0.5 & 0.9 & 1.2 & 1.9 & 1.2 & 0.9 & 0.5 & 0.3 & & cal crossbite \\
\hline & & 5 & & & 0.8 & 1.2 & 1.9 & 3.0 & 1.9 & 1.2 & 0.8 & 0.5 & & May be: \\
\hline $\begin{array}{l}\text { - Sum of } t \\
>45^{\circ} \text { or }>2 r\end{array}$ & $\begin{array}{l}\text { teeth rotated } \\
\mathrm{mm} \text { displaced }\end{array}$ & 6 & & & 1.1 & 1.8 & 2.8 & 4.3 & 2.8 & 1.8 & 1.1 & 0.7 & & $\begin{array}{l}\text { YES: - maxilla } \\
\text { - expansion }\end{array}$ \\
\hline & $\times 2$ & 7 & & & 1.5 & 2.4 & 3.9 & 5.9 & 3.9 & 2.4 & 1.5 & 1.0 & & - Brodie syn- \\
\hline & & 8 & & & 19 & 3.1 & 4.9 & 7.7 & 4.9 & 3.1 & 19 & 1.3 & & drome \\
\hline $\begin{array}{r}\text { - Total ( } \\
\text { cou }\end{array}$ & $\begin{array}{l}0,1 \text { without } \\
\text { unting) }\end{array}$ & 9 & & & 2.5 & 4.1 & 6.2 & 9.7 & 6.2 & 4.1 & 2.5 & 1.7 & & $\begin{array}{l}\text { NO: - maxilla } \\
\text { - collapse }\end{array}$ \\
\hline & & $>9$ & & & 3.0 & 4.9 & 7.7 & $10+$ & 7.7 & 4.9 & 3.0 & 2.0 & & $\begin{array}{l}\text { - posterior } \\
\text { crossbite }\end{array}$ \\
\hline & Constants & & & 17 & 3.95 & 2.72 & 1.50 & 0.27 & 1.50 & 2.72 & 3.95 & 5.17 & & \\
\hline & Buccal up- & No. & 0 & 1 & 2 & 3 & 4 & 5 & 6 & 7 & 8 & More & & \\
\hline $\begin{array}{l}\text { (8) Sum of } \\
\text { teeth in }\end{array}$ & $\begin{array}{c}\text { per posterior } \\
\text { teeth }\end{array}$ & Weight & 0 & 0.1 & 0.6 & 1.3 & 2.2 & 3.5 & 5.0 & 6.9 & 9.0 & 10 & & \\
\hline posterior & Lingual upper & No. & 0 & 1 & 2 & 3 & 4 & 5 & 6 & & More & & & \\
\hline & $\begin{array}{l}\text { posterior } \\
\text { teeth }\end{array}$ & Weight & 0 & 0.3 & 1.0 & 2.3 & 4.2 & 6.5 & 9.4 & & 10 & & & \\
\hline
\end{tabular}


There were significant differences $(p<0.001)$ in the mean overjet and overbite between the cases and controls (Table 3). Moreover, the prevalence of mild tooth displacements (rotation up to 45 degree or displacement up to $2 \mathrm{~mm}$ ) and severe tooth displacements (rotation $>45$ degree or displacement $>2 \mathrm{~mm}$ ) were 1.8 times and 3.5 times greater in the cases, as compared to the controls, respectively.
According to TPI, majority of thalassemic children had MSE grade 4 and 5 malocclusion, as compared to grade 2 and 3 in controls. Severe forms of malocclusions were significantly $(p<0.001)$ more prevalent in thalassemic children, as compared to the controls (Fig. 2). The mean TPI score for thalassemic children was $8.55 \pm 4.13$, which was significantly higher $(p<0.001)$ than that in normal children, which was recorded as $4.09 \pm 3.27$.

Table 2 - Comparison of Angle's classification between cases and controls

\begin{tabular}{|c|c|c|c|c|}
\hline $\begin{array}{l}\text { Angle's classification of } \\
\text { molar relationship }\end{array}$ & $\begin{array}{l}\text { Thalassemic children } \\
\qquad(n=200)\end{array}$ & $\begin{array}{l}\text { Healthy controls } \\
\qquad(n=200)\end{array}$ & Total & $p$ value \\
\hline Class I & 76 & 135 & 173 & \multirow{3}{*}{$<0.001$} \\
\hline Class II & 118 & 49 & 108 & \\
\hline Class III & 6 & 16 & 19 & \\
\hline
\end{tabular}

Table 3 - Comparison of different occlusal parameters between cases and the controls.

\begin{tabular}{|c|c|c|c|c|}
\hline & Thalassemic children $n=200$ & Healthy controls $n=200$ & Mean difference & $p$ value \\
\hline Overjet (mm) & $4.17 \pm 2.64$ & $2.90 \pm 2.31$ & 1.27 & $<0.001^{*}$ \\
\hline Overbite (mm) & $4.18 \pm 2.88$ & $3.14 \pm 1.91$ & 1.04 & $<0.001^{*}$ \\
\hline Teeth mildly displaced & $4.37 \pm 3.10$ & $2.49 \pm 2.05$ & 1.88 & $<0.001^{* *}$ \\
\hline Teeth severely displaced & $2.09 \pm 2.64$ & $0.59 \pm 0.95$ & 1.50 & $<0.001^{\star *}$ \\
\hline Number of patients with buccal/lingual crossbite & 20 & 8 & $6 \%$ & $0.079 * *$ \\
\hline
\end{tabular}

* Independent sample t-test. ** Chi-square test.
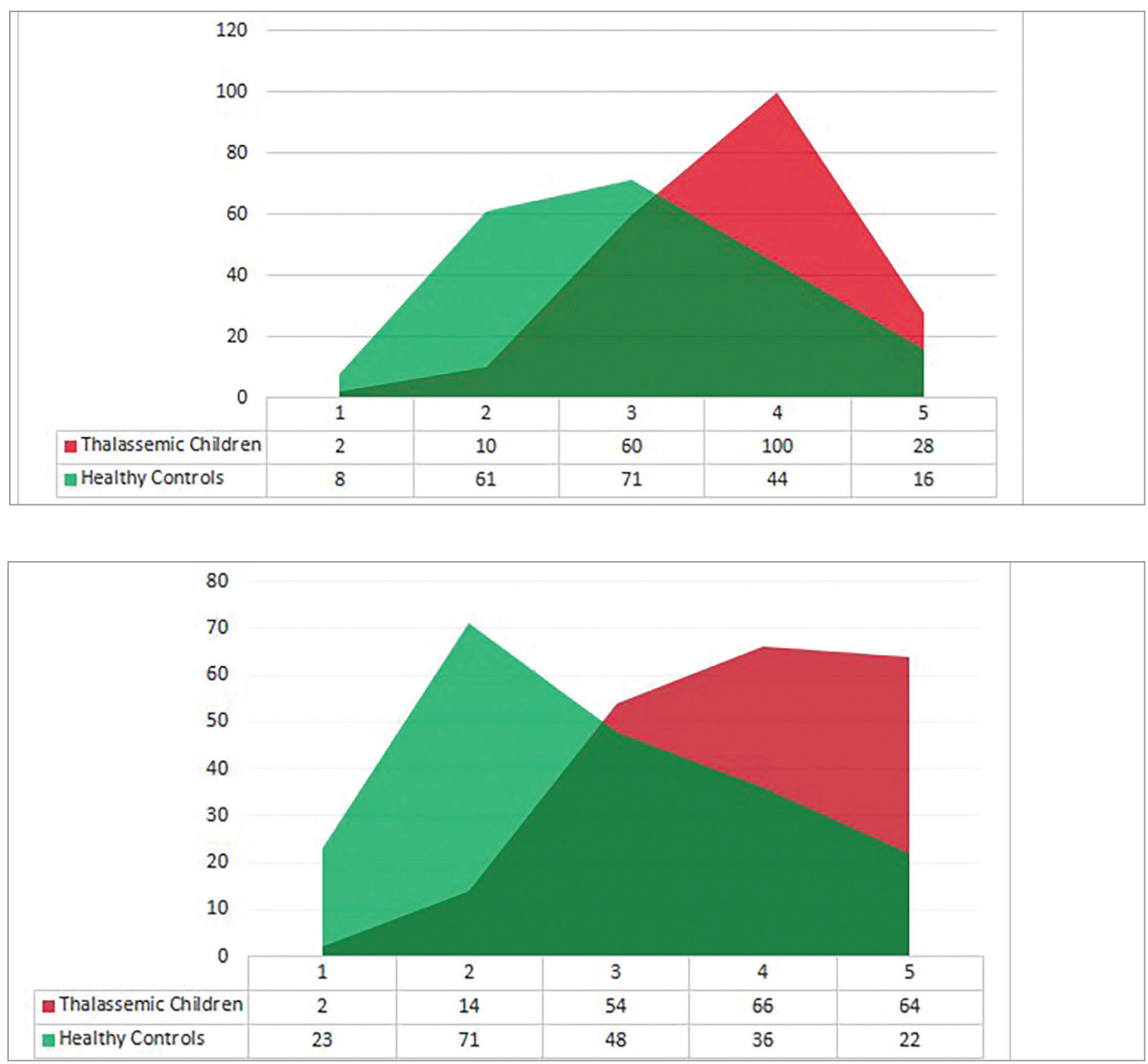

Figure 1 - Distribution of cases and controls into five grades of IOTN-DHC.

Figure 2 - Distribution of cases and controls into TPI grades of MSE. 


\section{DISCUSSION}

Patients suffering from $\beta$-thalassemia major usually become dependent on regular blood transfusions early in life. However, the dental features become noticeable when the permanent teeth start to erupt and child enters puberty. So, patients aged 11-17 years were included in this study, which also marks the time when orthodontic treatment is usually sought.

There are several indices to evaluate the severity of malocclusion, such as American Board of Orthodontics Discrepancy Index (ABO-DI), Summer's Occlusal Index, and Grainger's TPI. ABO-DI requires cephalometric assessment along with the clinical examination, which makes it impractical to apply for patient when no actual treatment is being provided. On the other hand, occlusal index is relatively complicated and requires more clinical time, as compared to TPI. ${ }^{19}$ Thus, we used Grainger's TPI, which is not only reproducible and valid, but has also proven to be a useful tool for epidemiological assessment of malocclusion. ${ }^{20,21}$

In the present study, the subjects with thalassemia were found to have greater prevalence of skeletal Class II, increased overjet and both mild and severe tooth displacements, as compared to the controls. In the extraoral aspect, these children had a tendency towards convex facial profile due to maxillary prognathism and incompetent lips. The typical extraoral and intraoral clinical features of transfusion-dependent children with $\beta$-thalassemia are shown in Figures 3 and 4. Enlarged maxillary bone marrow due to extracellular haematopoiesis and lack of oral hygiene awareness may well have contributed to the aforementioned malocclusion. The statistics from the current and previous studies reveal that thalassemic patients consistently have greater prevalence of Angle's Class II malocclusion, reported to be $55 \%$ by Gupta et al, ${ }^{22}$ and $51 \%$ by Shahsevari et al, ${ }^{23}$ as compared to $59 \%$ in the current study.
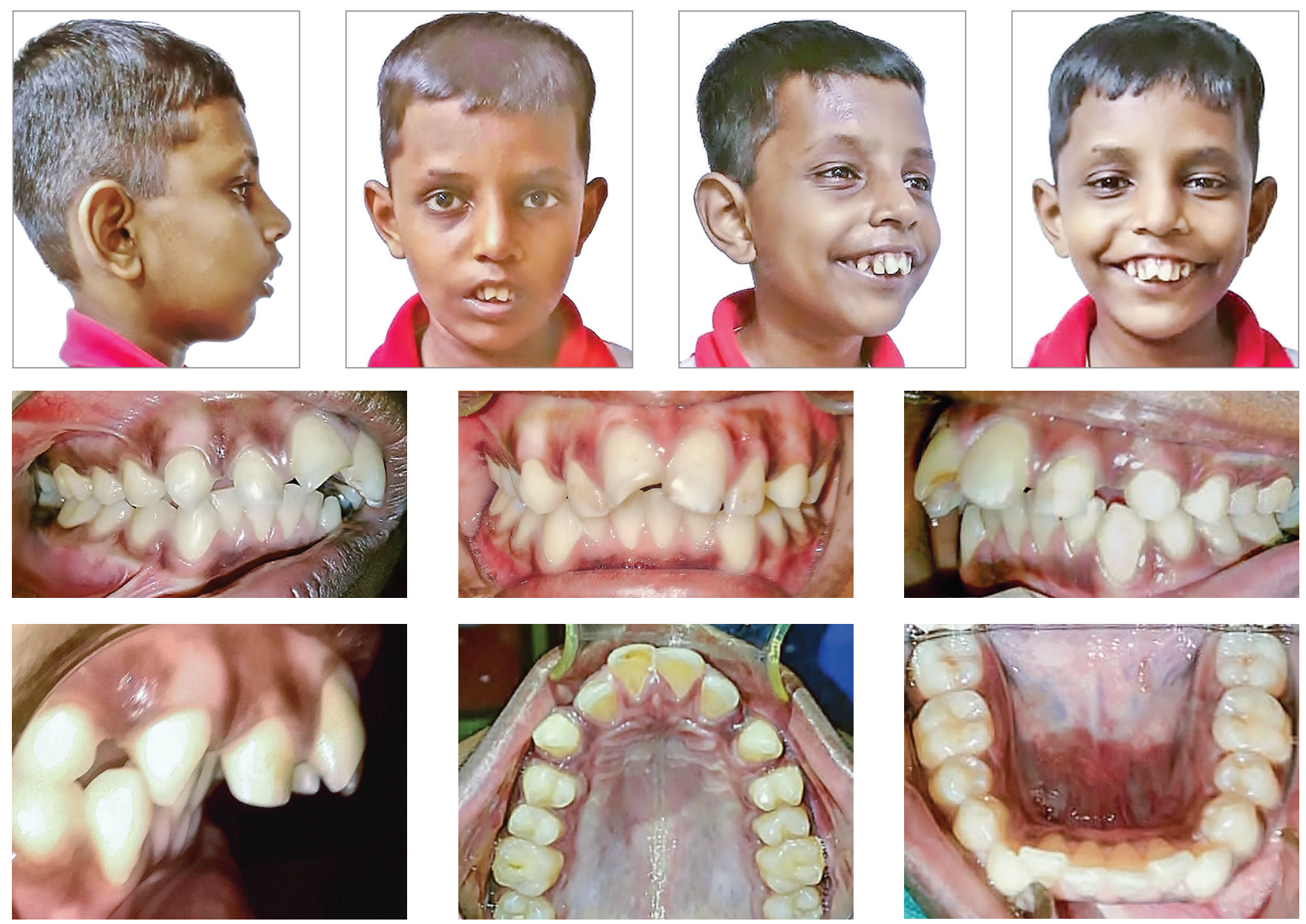

Figure 3 - Patient presenting convex facial profile with incompetent lips. Note fractured edge of maxillary right central incisor, which is not an uncommon finding in patients with excessive proclination of maxillary incisors. 
The statistics also reveal that around 84\% and 65\% of the thalassemic patients lie in the IOTN moderate to severe treatment need groups, and MSE handicapping and severely handicapping malocclusion groups, respectively. Thus about two-thirds to three-fourths of transfusion-dependent thalassemic children required definitive orthodontic treatment. Gupta et a ${ }^{22}$ used Grainger's TPI and found that $68 \%$ of their thalassemic sample had definitive to severely handicapping malocclusion. The current study reports that $29 \%$ of healthy children had handicapping to severely handicapping malocclusion. The reported percentage of healthy school children needing definitive orthodontic treatment ranges from 18 to 26 percent in other studies, which is similar to the present findings. ${ }^{22,24,25}$

The similarities between the present results and those of Gupta et $\mathrm{al}^{22}$ are remarkable. This might be due to similar selection criteria and subcontinental origin of the sample. Majority of the thalassemic patients in the world are located in South Asian countries like India, Pakistan and Bangladesh. ${ }^{26}$ According to one estimate, about 10 million individuals in Pakistan suffer from thalassemia minor, while more than 50,000 have thalassemia major. ${ }^{27,28}$ Most of these patients are being treated by nongovernmental organizations, which have limited resources. The sample of thalassemic children in the current study was also collected from transfusion centers run by one of such organizations. A single center study reports that the treatment provided at these centers is not optimum, and majority of the thalassemic children are under-transfused. ${ }^{29}$ This might explain greater severity of malocclusion in the present sample, as compared to that reported in literature for other population groups. 22,23

As the dental and orthodontic complications are not life threatening, they are likely to be ignored by the affected individual and the medical specialists. As a conse-
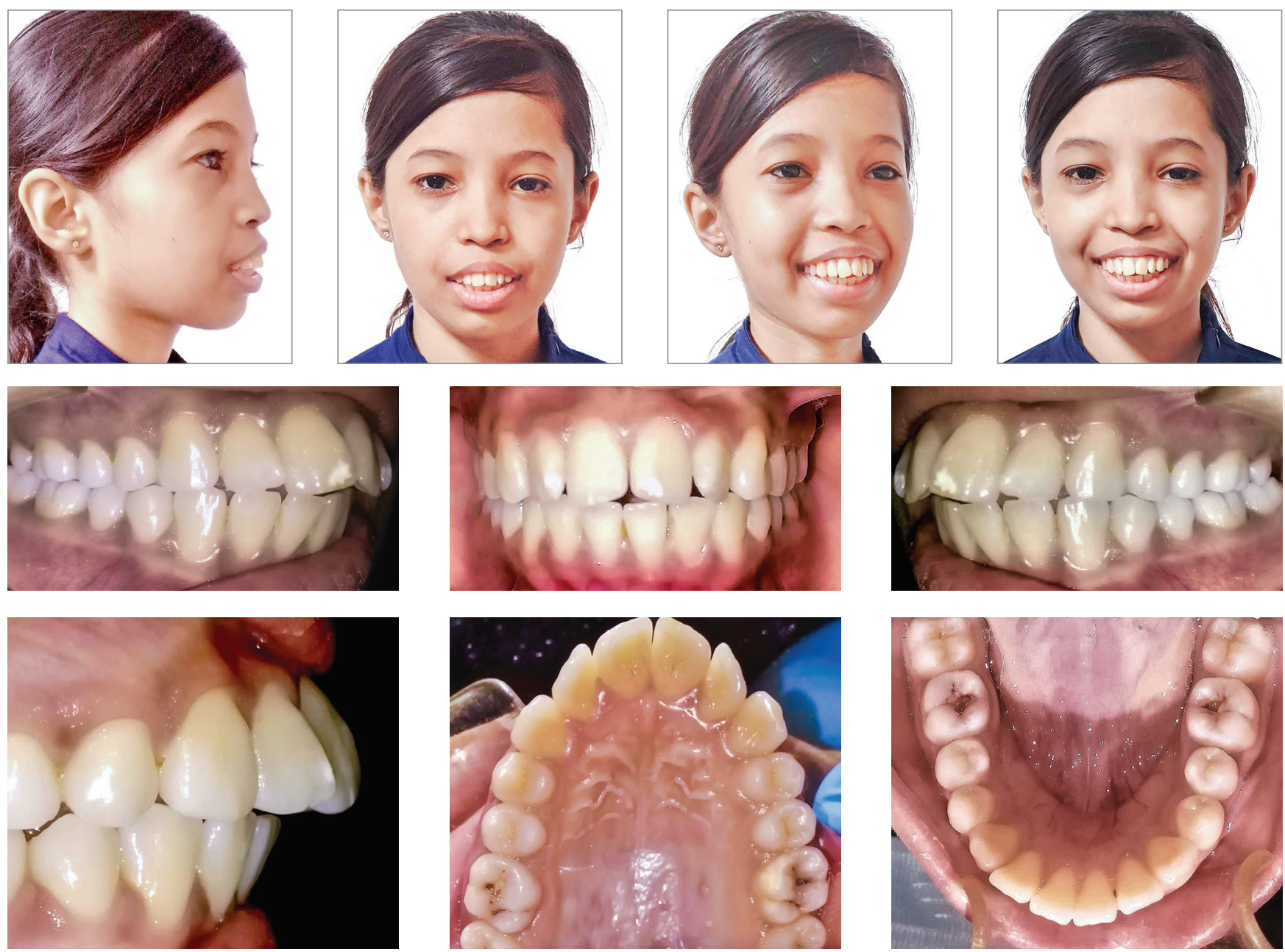

Figure 4 - A typical female patient showing features of skeletal Class II malocclusion due to maxillary prognathism, Class II division 1 malocclusion with proclined incisors and an increased overjet. 
quence, these problems tend to worsen over time. A preventive and interceptive orthodontic treatment approach is required in these patients, to reduce the likelihood of trauma, to improve stomatognathic function and the facial appearance. ${ }^{30}$ In the present sample, the age at first transfusion ranged from 6 months to 6 years. Hakeem et $\mathrm{al}^{31}$ have shown that starting transfusions in older age is a protective factor against poor quality of life. Authors recommend that the relationship between the severity of malocclusion in these children and the age of starting transfusions should be assessed on a larger sample.

Effective orthodontic treatment interventions usually comprise of high-pull headgear and functional appliances, to restrict maxillary sagittal and vertical growth, as well as to enhance mandibular growth. As these patients usually have to undergo regular blood transfusions, hence orthognathic surgeries need to be avoided if possible. ${ }^{32}$ Thus, early intervention, interceptive treatment and growth modifications are usually the treatment of choice in these patients..$^{30,32}$

The dental and orthodontic treatment modalities may significantly contribute to the generalized well-being and improved quality of life in these patients. Based on the staggering findings of the current study, it is recommended to have continuous orthodontic supervision for transfusiondependent thalassemic children, similar to those for the patients with craniofacial syndrome and cleft lip and palate.

\section{CONCLUSION}

Majority of thalassemic children suffer from Class II malocclusion; in contrast to normal children, who most commonly have Class I malocclusion. The IOTNDHC grades and TPI-MSE depict that the malocclusion in thalassemic children is much more severe and handicapping. Since the life expectancy of these children has improved over the last few decades, more expertise and resources need to be allocated to cater the orthodontic treatment needs of these children.

\section{Authors contribution (ORCID ${ }^{(1)}$ )}

Waqar Jeelani (WJ): 0000-0003-0109-3117

Uroosa Sher (US): 0000-0002-9358-0475

Maheen Ahmed (MA): 0000-0003-0806-7739 리

Conception or design of the study: WJ, US, MA. Data acquisition, analysis or interpretation: WJ, US, MA. Writing the article: WJ, US, MA. Critical revision of the article: WJ, US, MA. Final approval of the article: WJ, US, MA. Overall responsibility: WJ, US, MA. 


\section{REFERENCES}

1. Galanello R, Origa R. Beta-thalassemia. Orphanet J Rare Dis. 2010 May 21:5:11

2. Cao A, Galanello R. Beta-thalassemia. Genet Med. 2010 Feb:12(2):61-76

3. Vichinsky EP. Changing patterns of thalassemia worldwide. Ann N Y Acad Sci. 2005:1054:18-24

4. Ahmed S, Saleem M, Modell B, Petrou M. Screening extended families for genetic hemoglobin disorders in Pakistan. N Engl J Med. 2002 Oct 10;347(15):1162-8

5. Modell B, Darlison M. Global epidemiology of haemoglobin disorders and derived service indicators. Bull World Health Organ. 2008 June; $86(6): 480-7$

6. Weatherall DJ, Clegg JB. The thalassemia syndromes. 4th ed. Oxford Blackwell Science Ltd; 2001

7. Greer JP, Foerster J, Rodgers GM, Paraskevas F, Glader B, Arber DA Wintrobe's clinical hematology. Philadelphia: Lippincott Williams \& Wilkins; 2008

8. Schwartz E, Benz E, Forget B. Thalassemiasyndromes. In: Hoffman R, Benz E, Shattil S, editors. Hematology: basic principles and practice. 2th ed. New York: Churchill Livingstone; 1995

9. Baker DH. Roentgen manifestations of Cooley's anemia. Ann NY Acad Sci. 1964 Oct 7:119:641-61.

10. Hattab FN. Patterns of physical growth and dental development in Jordanian children and adolescents with thalassemia major. J Oral Sci. 2013 Mar;55(1):71-7.

11. Hattab FN. Periodontal condition and orofacial changes in patients with thalassemia major: a clinical and radiographic overview. J Clin Pediatr Dent. 2012 Spring:36(3):301-7.

12. Madhok S, Madhok S. Dental considerations in thalassemic patients. J Dent Med Sci. 2014 June:13(6):57-62

13. Einy S, Hazan-Molina H, Ben-Barak A, Aizenbud D. Orthodontic consideration in patients with beta-thalassemia major: case report and literature review. J Clin Pediatr Dent. 2016;40(3):241-6.

14. Park N, Lazow S, Berger J. B-Thalassemia: medical and surgical considerations in managing facial deformities: case report and review of literature. J Oral Maxillofac Surg. 2012 Apr;70(4):e284-9

15. Weatherall DJ, Clegg JB. Inherited haemoglobin disorders an increasing global health problem. Bull World Health Organ. 2001;79(8):704-12.

16. Taher A, Vichinsky E, Musallam K, Cappellini M, Viprakasit V, Weatherall D, editors. Guidelines for the management of non transfusion dependent thalassaemia (NTDT). Nicosia (Cyprus): Thalassaemia International Federation; 2013.

17. Grainger RM. Orthodontic treatment priority index. Vital Health Stat 2. 1967 Dec;25:1-49

18. Brook PH, Shaw WC. The development of an index of orthodontic treatment priority. Eur J Orthod. 1989 Aug:11(3):309-20.

19. Tang EL, Wei SH. Recording and measuring malocclusion: a review of the literature. Am J Orthod Dentofacial Orthop. 1993 Apr;103(4):344-51.
20. Ghafari J, Locke SA, Bentley JM. Longitudinal evaluation of the treatment priority index (TPI). Am J Orthod Dentofacial Orthop. 1989 Nov:96(5):382-9.

21. Hermanson PC, Grewe JM. Examiner variability of several malocclusion indices. Angle Orthod. 1970 July:40(3):219-35

22. Gupta DK, Singh SP, Utreja A, Verma S. Prevalence of malocclusion and assessment of treatment needs in $\beta$-thalassemia major children. Prog Orthod. 2016:17:7

23. Shahsevari F, Eslami M. Ferhvesh MH. Malocclusion in subjects with beta-thalassemia major. J Semnan University Med Sci. 2007; 8(4):211-26.

24. Esa R, Razak IA, Allister JH. Epidemiology of malocclusion and orthodontic treatment need of 12-13-year-old Malaysian school children. Community Dent Health. 2001 Mar;18(1):31-6.

25. van Wyk PJ, Drummond RJ. Orthodontic status and treatment need of 12-year-old children in South Africa using the dental aesthetic index. SADJ 2005 Sept;60(8):334-6, 338

26. Hossain MS, Raheem E, Sultana TA, Ferdous S, Nahar N, Islam S, et al. Thalassemias in South Asia: clinical lessons learnt from Bangladesh. Orphanet J Rare Dis. 2017 May 18:12(1):93.

27. Khattak MF, Saleem M. Prevalence of heterozygous beta-thalassemia in Northern areas of Pakistan. J Pak Med Assoc. 1992 Feb;42(2):32-4.

28. Ahmed S. An approach for the prevention of thalassaemia in Pakistan. [thesis]. London: University College London Medical School; 1998.

29. Ahmed S, Wazir ZJ, Qayyum IA. Clinical and haematological picture of multi-transfused thalassaemia major patients at a center in Pakistan. J Islam Int Med Coll. 2018;13(2):52-6.

30. Kumar N, Hattab FN, Porter J. Dental Care. In: Cappellini MD, Cohen A, Porter J, Taher A, Viprakasit V, editors. Guidelines for the management of transfusion dependent thalassaemia (TDT). 3th ed. Nicosia (CY) Thalassaemia International Federation; 2014

31. Hakeem GLA, Mousa SO, Moustafa AN, Mahgoob MH, Hassan EE. Health-related quality of life in pediatric and adolescent patients with transfusion-dependent ß-thalassemia in upper Egypt (single center study). Health Qual Life Outcomes. 2018 Apr 10;16(1):59

32. Einy S, Hazan-Molina H, Ben-Barak A, Aizenbud D. Orthodontic consideration in patients with beta-thalassemia major: case report and literature review. J Clin Pediatr Dent. 2016;40(3):241-6. 